\title{
Electroconvulsive Therapy Increases Plasma Levels of Interleukin-6 ${ }^{a}$
}

\author{
ZIAD KRONFOL, ${ }^{b}$ LIN LEMAY, ${ }^{c}$ MADHAVAN NAIR, ${ }^{d}$ \\ AND MATTHEW KLUGER ${ }^{c}$ \\ Departments of ${ }^{b} P_{\text {sychiatry, }}{ }^{\text {Physiology, and }}{ }^{d}$ Pediatrics \\ University of Michigan Medical Center \\ Ann Arbor, Michigan 48109
}

There is now ample evidence of close interactions between the central nervous system and the immune system. Neurohormones and neurotransmitters play an important role in immunomodulation. Similarly, products of the immune system contribute to neuroendocrine secretion and may also possess specific behavioral properties. Animal studies have shown that stress can interfere with immune regulation and mediate the release of interleukins. Human studies assessing interactions between stress and immunity have been relatively scarce. We have reported earlier that patients suffering from a major depression show a decrease in natural killer (NK) cell activity. ${ }^{1}$ We have also shown that electroconvulsive therapy (ECT), an effective and well known treatment for depression, increases NK cytotoxicity. ${ }^{2}$ We therefore formulated the hypothesis that ECT will also be accompanied by an increase in plasma levels of interleukin-6 (IL-6).

Eight hospitalized psychiatric patients who were suffering from affective disorders and who were referred to the ECT service by their attending physicians were included in the study. Their mean age was $48.9 \mathrm{yr}$ (range $=17$ to $82 \mathrm{yr}$ ). Four patients were male, four were female. The purpose of the study was explained to each subject and an informed consent was obtained. Venous blood samples were drawn from a previously inserted forearm catheter at two time points in relation to the first ECT: immediately before ECT treatment and $10 \mathrm{~min}$ after ECT. The blood samples were centrifuged immediately after drawing and the plasma was frozen and kept at $-70^{\circ}$ C. The frozen samples were later thawed and IL-6 activity was measured using the IL-6-dependent B-9 hybridoma cell line kindly provided by Dr. Lucien Aarden. One hundred $\mu \mathrm{l}$ of 1:10 diluted plasma sample was combined with $5000 \mathrm{~B} 9$ cells in $100 \mu \mathrm{l}$ IMDM $/ 5 \%$ FCS in flat-bottom microtiter plates for a final volume of $200 \mu \mathrm{l}$. All samples were run in duplicate. The control medium, which contained no IL-6, was run in quadruplicate. In addition to the undiluted plasma samples, a serial dilution of each sample was assayed. Cells were pulsed at 68 to $72 \mathrm{~h}$ with $0.5 \mu \mathrm{Ci}$ $\left[{ }^{3} \mathrm{H}\right]$ thymidine, harvested onto glass fiber filter strips, and the radioactivity incorporated into DNA was counted by a $\beta$-scintillation counter. For each assay, a standard

${ }^{a_{\text {This }}}$ work was supported in part by U.S. Public Health Service Grants MH42988 and AA07378. 
curve was run with recombinant human IL-6. One unit of IL-6 is equal to the amount that caused half-maximum proliferation in the standard curve. From this standard curve, a best-fit regression was calculated for the rising portion of the curve in the linear range. The equation for this best fit line was used to calculate IL- 6 activity in plasma samples.

Concentrations of IL- 6 before and after ECT are shown in FIGURE 1. Levels of IL- 6 before ECT showed a wide range of variation (mean $=130.6 \mathrm{U} / \mathrm{ml}$, range 39.5 to $552.0 \mathrm{U} / \mathrm{ml}$ ). Similarly, IL-6 levels after ECT also showed a wide range (mean=372.1

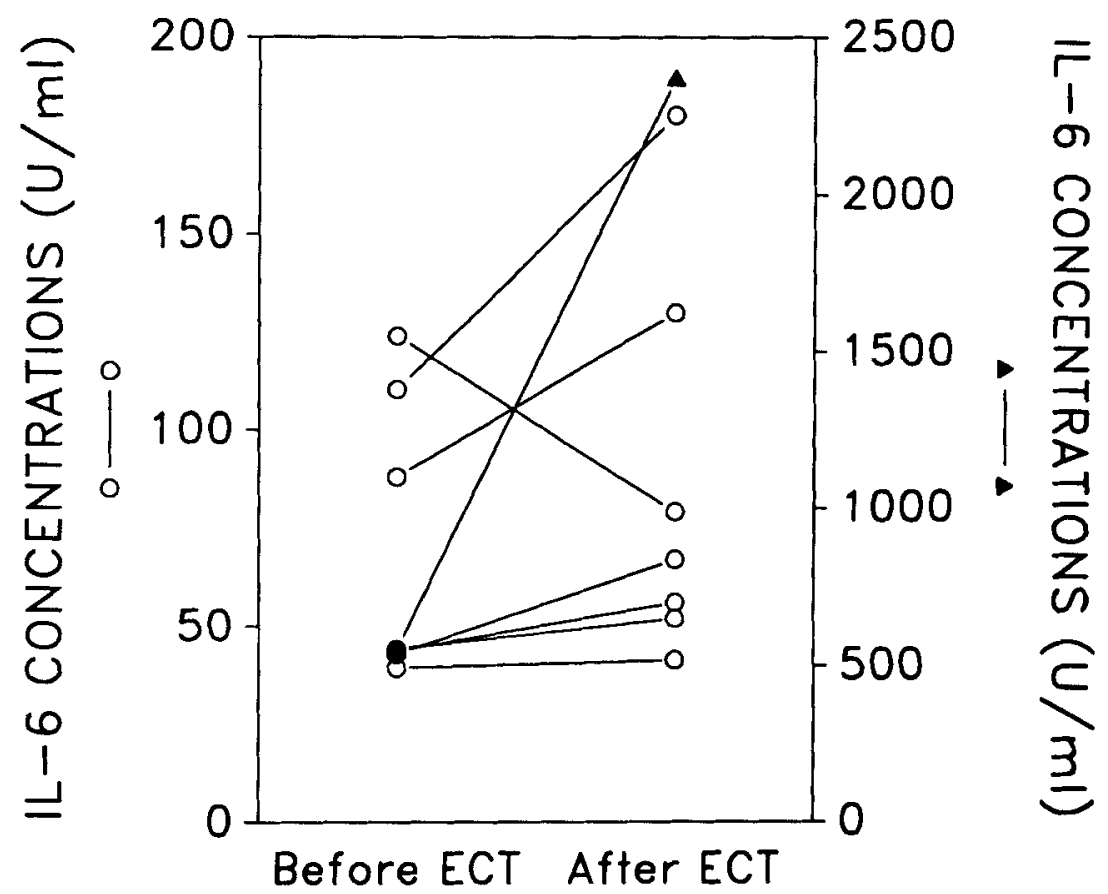

FIGURE 1. Plasma concentrations of interleukin-6(IL-6) immediately before and $10 \mathrm{~min}$ after electroconvulsive therapy (ECT). The values after ECT were higher than corresponding preECT values in seven of the eight patients studied.

$\mathrm{U} / \mathrm{ml}$; range $=41.5$ to $2,371.0 \mathrm{U} / \mathrm{ml}$ ). However, as FigurE 1 shows, in seven of the eight patients studied, the IL-6 levels after ECT were higher than the corresponding pre-ECT values. These results were statistically significant using the non-parametric sign test $(X=1, n=8, p=0.035$, one-tail).

The mechanisms leading to the increase in plasma levels of IL- 6 following ECT are not clear. It is possible that this increase in IL-6 may be the result of an increase in IL-1. IL-1 immunoreactivity has been demonstrated in brain cells. ${ }^{3}$ Furthermore, IL-1 has been shown to increase the secretion of hormones such as ACTH and cortisol, which are also increased following ECT. ${ }^{4}$ It is also possible that ECT stimulates the release of IL-6 directly. Preliminary evidence suggests that IL- 6 can 
be secreted by hypothalamic neurons in vitro, particularly in the presence of lipopolysaccharide (LPS). ${ }^{5}$ The secretion of IL- 6 has also been shown to increase in vivo following certain forms of stress. ${ }^{6}$ Whatever the mechanisms involved, our results showing an increase in plasma levels of IL-6 following ECT provide yet another example of close interactions between the brain and the immune system. The clinical implications of these findings remain to be determined.

\section{REFERENCES}

1. Kronfol, Z., M.P.N. Nair, J. Goodson, K. Goel, R. Haskett \& R. Schwartz. 1990. Natural Killer cell activity in depressive illness: preliminary report. Biol. Psychiatry 26:753-756.

2. Kronfol, Z., J. Goodson, K. Goel, M.P.N. Nair \& L. Grunhaus. 1990. Acute effects of ECT on natural killer cell activity. Biol. Psychiatry 25:90A.

3. Breder, C., C. Dinarello \& C. SAPER. 1988. Interleukin-1 immunoreactive innervation of the human hypothalamus. Science 240:321-324.

4. Aperia, B., M. Thoren, M. ZetTergen \& L. Wettenberg. 1984. Plasma pattern of adrenocorticotropin and cortisol during electroconvulsive therapy in patients with major depressive illness. Acta Psych. Scand. 70:361-369.

5. Spangelo, B.L., I.S. Login, A.M. Judd, P.C. Isakson \& R.M. McLeod. 1989. Release of interleukin-6 from rat hypothalamus. Soc. Neurosci. Abstr. 15:8. (Abstract \#7.10)

6. LEMAY, L.G., A.J. VANDER \& M.J. KLuger. 1990. The effects of psychological stress on plasma interleukin 6 activity in rats. Physiol. Behav. In press. 